\title{
Social Worker
}

National Cancer Institute

\section{Source}

National Cancer Institute. Social Worker. NCI Thesaurus. Code C28190.

A professionally trained person who is employed in the administration of charity, social service, and welfare. The assistance this professional provides helps disadvantaged individuals and families adjust themselves to the community. Social workers work closely with health agencies, and are often employed by the government. 